\title{
Training - overtraining: performance, and hormone levels, after a defined increase in training volume versus intensity in experienced middle- and long-distance runners
}

\author{
M. Lehmann MD, U. Gastmann MD, K. G. Petersen MD*, N. Bachl MD, \\ A. Seidel cand. med., A. N. Khalaf MD*, S. Fischer Dipl. oec. troph. and J. Keul MD \\ Department of Sports and Performance Medicine and *Department of Endocrinology, University Clinic Freiburg, \\ Freiburg, Germany
}

Performance and hormones were determined in eight middle- and nine long-distance runners after an increase in training volume (ITV, February 1989) or intensity (ITI, February 1990). Seven runners participated in both studies. The objective was to cause an overtraining syndrome. The mean training volume of $85.9 \mathrm{~km}^{\text {week }}{ }^{-1}$ increased within 3 weeks to $176.6 \mathrm{~km}^{\text {week }}{ }^{-1}$ during ITV and $96-98 \%$ of training volume was performed as long-distance runs at mean(s.d.) $67(8) \%$ of maximum capacity. Speed endurance, high-speed and interval runs averaging $9 \mathrm{~km}$ week $^{-1}$ increased within 3 weeks to $22.7 \mathrm{~km}$ during ITI, and the total volume increased from 61.6 to $84.7 \mathrm{~km}$. A plateau in endurance performance and decrease in maximum performance occurred during ITV, probably due to overtraining, with performance incompetence over months. Nocturnal catecholamine excretion decreased markedly $(47-53 \%)$, contrary to exercise-related plasma catecholamine responses, which increased. Resting and exercise-related cortisol and aldosterone levels decreased. Improvement in endurance and maximum performance occurred during ITI indicating a failure to cause an overtraining syndrome in ITI. Decrease in noctural catecholamine excretion was clearly lower (9-26\%), exercise-related catecholamine responses showed a significant decrease, cortisol and aldosterone levels remained almost constant, exercise-related prolactin levels decreased slightly. There were no differences in insulin, C-peptide, free testosterone, somatotropic hormone (STH), follicle stimulating hormone (FSH), luteinizing hormone (LH), thyroid stimulating hormone (TSH), tri-iodothyronine $\left(T_{3}\right)$ and thyroxine $\left(T_{4}\right)$. The decrease in nocturnal catecholamine excretion during ITV might indicate a decrease in intrinsic sympathetic activity in exhausted sportsmen. But it remains open whether this reflected a central nervous system incompetence.

Keywords: Training, catecholamines, hormones

The overtraining syndrome describes a chronic imbalance between training and recovery in athletes with accumulation of fatigue, different physical and

Address for correspondence: Professor Dr M. Lehmann, University Clinic Freiburg, Department of Sports and Performance Medicine, Hugstetter Strasse 55, D-7800 Freiburg, Germany

(C) 1992 Butterworth-Heinemann Ltd 0306-3674/92/040233-10 psychological symptoms and performance incompetence over weeks and months ${ }^{1-3}$. It has to be differentiated from short-term overtraining (overreaching) and local muscular overstrain ${ }^{1,3}$. From a clinical and descriptive standpoint ${ }^{1}$, the overtraining syndrome can be divided into hypothetical parasympathetic and sympathetic types which describe the clinical pattern not the pathophysiological basis. To examine the hypothesis of a neuroendocrine, autonomic nervous system, or hormonal impairment ${ }^{1-3}$, we performed two prospective experimental training studies with the objective of producing an experimental overtraining syndrome in experienced middle- and long-distance runners.

\section{Subjects and methods}

Anthropometric data are summarized in Table 1 . The middle- and long-distance runners were acquainted with laboratory examination procedures. Eight athletes participated in the ITV study in February 1989, nine in the ITI study in February 1990, and seven in both studies. All athletes were informed about procedure and objective. They granted informed consent in writing and received DM1000 for participation in each study. Ethics Commission approval was obtained.

\section{Diet}

The athletes maintained their customary diet without alteration. No dietary concentrates, mineral beverages, vitamins or any medication were permitted (Table 2).

\section{Protocol}

Training volume and content were documented during the prephase of 1 week (Table 3). A 3-week training phase followed. During the ITV study, training was performed exclusively $(96-98 \%)$ as long-distance runs at mean(s.d.) $67(8) \%$ of maximum capacity.

Training volume increased by one-third per week, to about double the baseline values (Table 3 ). In the 
Table 1. Anthropometric data, oxygen uptake capacity $\left(\dot{V}_{\mathrm{O}_{2} \max }\right)$, and running experience of the athletes participating in the increase in volume study (ITV) and the increase in intensity study (ITI) at baseline (1) and final examination (2)

\begin{tabular}{|c|c|c|c|c|c|c|c|c|}
\hline & \multirow[t]{2}{*}{$n^{*}$} & \multirow{2}{*}{$\begin{array}{c}\text { Age } \\
\text { (years) }\end{array}$} & \multirow{2}{*}{$\begin{array}{l}\text { Height } \\
\text { (cm) }\end{array}$} & \multicolumn{2}{|c|}{ Weight (kg) } & \multicolumn{2}{|c|}{$\dot{V}_{O_{2 m a x}}\left(m / k^{-1} \min ^{-1}\right)$} & \multirow{2}{*}{$\begin{array}{c}\text { Running } \\
\text { experience } \\
\text { (years) }\end{array}$} \\
\hline & & & & 1 & 2 & 1 & 2 & \\
\hline $\begin{array}{l}\text { ITV } \\
\text { ITI }\end{array}$ & $\begin{array}{l}8 \\
9\end{array}$ & $\begin{array}{l}33(7) \\
34(7)\end{array}$ & $\begin{array}{l}179(4) \\
180(4)\end{array}$ & $\begin{array}{l}70(7) \\
73(4)\end{array}$ & $\begin{array}{l}70(6) \\
72(4) \ddagger\end{array}$ & $\begin{array}{l}66.8(5.6) \\
65.8(5.2)\end{array}$ & $\begin{array}{l}64.6(4.3) t \\
67.6(5.7) t\end{array}$ & $\begin{array}{l}5.6(1.3) \\
6.4(1.5)\end{array}$ \\
\hline
\end{tabular}

Values are mean(s.d.)

* Seven athletes participated in both studies; $+P<0.10 ; \ddagger P<0.05$; Dixon and Mood sign test

Table 2. Caloric supply

\begin{tabular}{lcc}
\hline & $\begin{array}{c}\text { Increase in } \\
\text { volume study }\end{array}$ & $\begin{array}{c}\text { Increase in } \\
\text { intensity study }\end{array}$ \\
\hline $\begin{array}{l}\text { Total caloric supply } \\
\text { per day (kcal) }\end{array}$ & $4110(942)$ & $3515(781)$ \\
Carbohydrates (\%) & $49(6)$ & $45(5)$ \\
Proteins (\%) & $14(3)$ & $13(2)$ \\
Lipids (\%) & $33(6)$ & $38(5)$ \\
Alcoholics(\%) & $4(3)$ & $3(3)$ \\
\hline
\end{tabular}

Values are mean(s.d.)

ITI study, speed endurance, high-speed and interval runs increased from $9 \mathrm{~km}$ (first week) to a mean of $22.7 \mathrm{~km}$ (fourth week). The overall volume increased from $61.6 \mathrm{~km}$ week ${ }^{-1}$ to $84.7 \mathrm{~km}$ week $^{-1}$, and the long-distance runs $(52.7-62.0 \mathrm{~km})$ were performed at a mean(s.d.) of $68(7) \%$ of maximum performance. Intensity training took place on Mondays (six to $10 \times$ 400-m interval runs at a mean(s.d.) of 70(4) s per 400-m run), Wednesdays (six to $10 \times 1000-\mathrm{m}$ high-speed runs at a mean(s.d.) of $86(6) \%$ of maximum performance), and Fridays (8000-10000-m speed-endurance runs at a mean(s.d.) of $77(7) \%$ of maximum capacity). No training took place on Sunday in either study. Speed endurance, highspeed and interval runs were performed in a stadium and were monitored continuously. Long-distance runs were performed on known cross-country courses and randomly controlled. The last 2 weeks of the first study were also controlled continuously.
Incremental treadmill tests took place on days 0 and 28. After the subjects had rested for $30 \mathrm{~min}$ in a supine position, venous blood was drawn before ergometry and immediately after exhaustion for determination of cortisol (RIA Cortisol Bridge, Serono, Freiburg, Germany), aldosterone (RIA Aldosterone, AIA, Serono, Freiburg, Germany), free testosterone (RIA Free Testosterone, Biermann, Bad Nauheim, Germany), insulin and C-peptide (RIAGnost Insulin and hC-Peptide, Behringwerke, Marburg), human growth hormone (hGH) (RIA hGH 100, Pharmacia Diagnostics, Uppsala, Sweden), prolactin (Prolactin AIA Clone, Serono, Freiburg, Germany), follicle stimulating hormone (FSH) and luteinizing hormone (LH) (FSH/LH AIA Clone Immunoradiometric Assay, Serono, Freiburg, Germany), thyroid stimulating hormone (TSH) (hTSH RIA-Gnost, Behringwerke, Marburg, Germany), triiodothyronine $\left(T_{3}\right) /$ thyroxine $\left(T_{4}\right)$ (free $T_{3} / T_{4}$ RIA, Becton, Dickinson, New York, USA). The analyses were performed by the same experienced technical assistant. All samples taken from one subject during one study were processed in one assay. The tests were performed on a motor-driven treadmill (Jäger, Würzburg, Germany; $1.5 \%$ slope) starting with a speed of $10 \mathrm{~km} \mathrm{~h}^{-1}$, which increased at 3-min intervals and a 30-s pause by $2 \mathrm{~km} \mathrm{~h}^{-1}$ to subjective exhaustion. Heart rate (from the electrocardiogram) and lactate levels (earlobe capillary blood, enzymatic ${ }^{4}$ were determined before exercise, immediately in each pause, and after termination of exercise. The catecholamine levels (earlobe capillary blood) were determined radioenzymatically, ${ }^{5,6}$ before exercise, at

Table 3. Training data

\begin{tabular}{|c|c|c|c|c|c|}
\hline & Week 1 & Week 2 & Week 3 & Week 4 & $\begin{array}{l}\text { Intensity as percentage of } \\
\text { maximum performance* }\end{array}$ \\
\hline $\begin{array}{l}\text { Increase in volume study } \\
\text { Training volume }(\mathrm{km})^{*} \\
\text { LDR (\%) } \\
\text { SDR/SR/IR (\%) }\end{array}$ & $\begin{array}{l}85.9(14.2) \\
92.7 \\
7.3\end{array}$ & $\begin{array}{l}115.1(17.5) \\
96 \\
4\end{array}$ & $143.1(20.0)$ & $\begin{array}{l}174.6(26.7) \\
98 \\
2\end{array}$ & $67(8)$ \\
\hline $\begin{array}{l}\text { Increase in intensity study } \\
\text { Training volume }(\mathrm{km})^{*} \\
\text { LDR (\%) } \\
\text { SDR (\%) } \\
\text { SR (\%) } \\
\text { IR (\%) }\end{array}$ & $\begin{array}{l}61.6(21.4) \\
85.2 \\
8.3 \\
5.9 \\
0.5\end{array}$ & $\begin{array}{l}62.9(6.0) \\
76.3 \\
10.8 \\
9.0 \\
3.8\end{array}$ & $\begin{array}{l}75.5(8.0) \\
75.4 \\
11.3 \\
9.2 \\
4.2\end{array}$ & $\begin{array}{l}84.7(9.0) \\
73.2 \\
11.3 \\
10.7 \\
4.7\end{array}$ & $\begin{array}{l}68(7) \\
77(7) \\
86(6) \\
70+(4)\end{array}$ \\
\hline
\end{tabular}




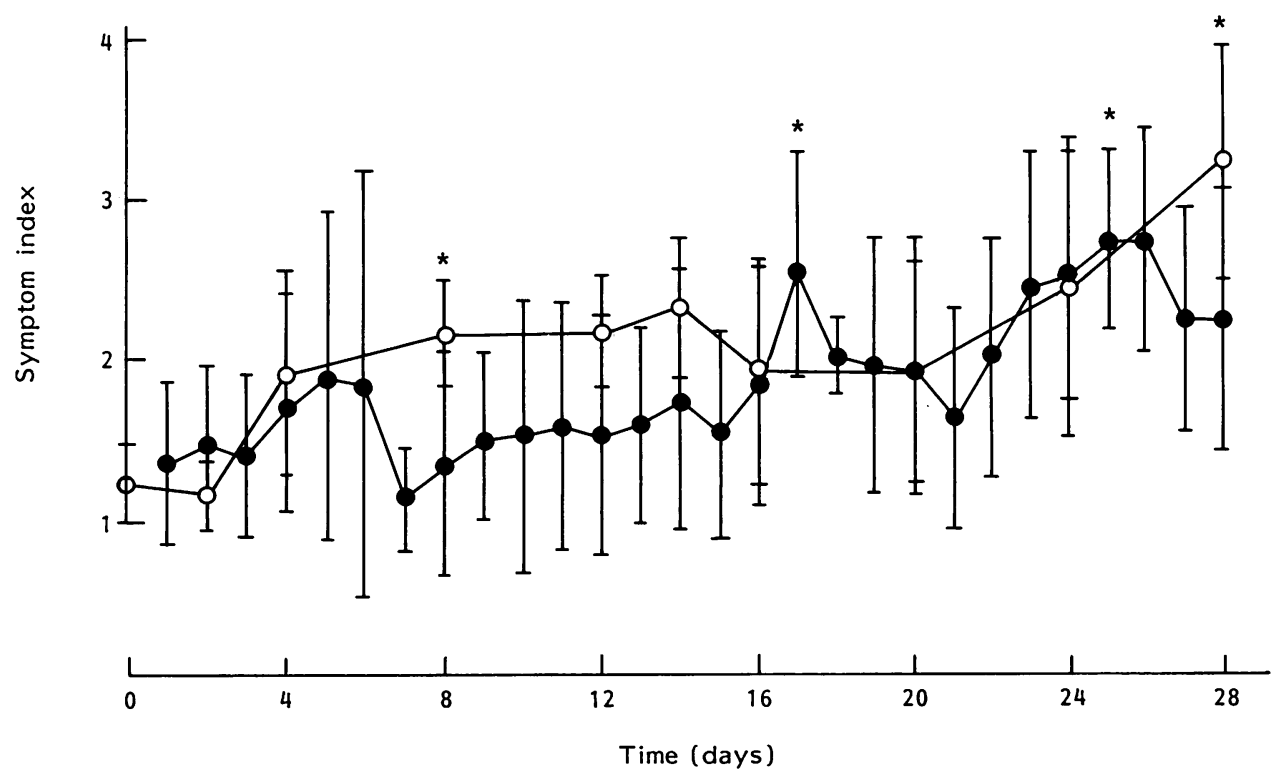

Figure 1. Symptom index during the increase in volume study $(O)$ and the increase in intensity study (O). ${ }^{*}$ The symptom index was significantly increased at day 8 compared with day 0 and at day 28 compared with days 0 and 8 during the increase in volume study $(P<0.05)$; a significant increase was observed at days 17, 25 and 26 compared with baseline values during the increase in intensity study $(P<0.05)$

the same submaximum level $\left(v=16 \mathrm{~h}^{-1}\right)$ and immediately after termination. The running velocity at the $4 \mathrm{mmol}$ lactate level was taken as an index of the endurance performance capacity and the total distance during incremental running as an index of maximum performance capacity.

The subjects kept a diary of heart rate on waking, body weight, training, diet (special recording sheets on 11 days of each study), and any kind of medical symptom. In addition, they rated their well-being daily on a four-point scale: 1 , no symptoms; 2 , mild; 3, moderate; 4, severe symptoms (Figure 1).

During the prephase of 1 week and the prospective training phase of 3 weeks, and for an additional week thereafter, the athletes collected total nocturnal urine on two nights week ${ }^{-1}$ in collection flasks prepared with hydrochloric acid (having an approximate $\mathrm{pH}$ value of 2) for determination of nocturnal catecholamine excretion ${ }^{5}$, which we took as a parameter of intrinsic sympathetic activity. Collection was made during a night after intensive training and a night after a day of relaxation, and the mean was taken. The 24-h urine was collected on another day each week to determine cortisol elimination.

\section{Assessment and statistics}

Means and standard deviations were calculated for performance-related data. The statistical examination within a group was made using the sign test of Dixon and $\operatorname{Mood}^{7}$, which is particularly critical for small random samples - if the data of two subjects (in a random sample of eight or nine subjects) differed in sign from 6-7 subjects (difference between baseline and final values), this only meant a probability of error of $P<0.10$ (not significant); if one subject differs, $P<0.05$ (significant); concordance of all eight or nine subjects resulted in $P<0.01$. The Wilcoxon, Mann-Whitney $U$ test $^{7}$ was used between the groups. Median values, $50 \%$ confidence range and overall range of data were determined for hormonal parameters and catecholamines. Statistical comparisons were performed using the sign test and the $U$ test.

\section{Results}

Anthropometric data are listed in Table 1 and performance behaviour is shown in Figure 2. Slight weight loss was observed during the ITI study. The running velocity at the $4 \mathrm{mmol}$ lactate level did not change in the ITV study and improved in the ITI study. The total running distance in the incremental test of six of the eight athletes decreased during the ITV study and increased in seven of nine athletes during the ITI study. Heart rate is given in Figure 3 and symptom index in Figure 1. The morning resting heart rate remained constant in both studies - it decreased before exercise, at identical exercise levels, and during maximum exercise in the ITV study. Symptoms such as exhaustion, fatigue, burn-out and muscle stiffness, were significantly increased during the ITV study compared with the ITI study.

Plasma catecholamines are listed in Table 4. The lower dopamine levels in the ITI compared with the ITV group most likely reflect inter-assay variability. No significant dopamine changes were observed in the two studies. Noradrenaline and adrenaline levels were in the same range in both studies, with the exception of differences in the adrenaline maxima. At the same exercise levels in the ITV study, there was an increase in noradrenaline and adrenaline re- 


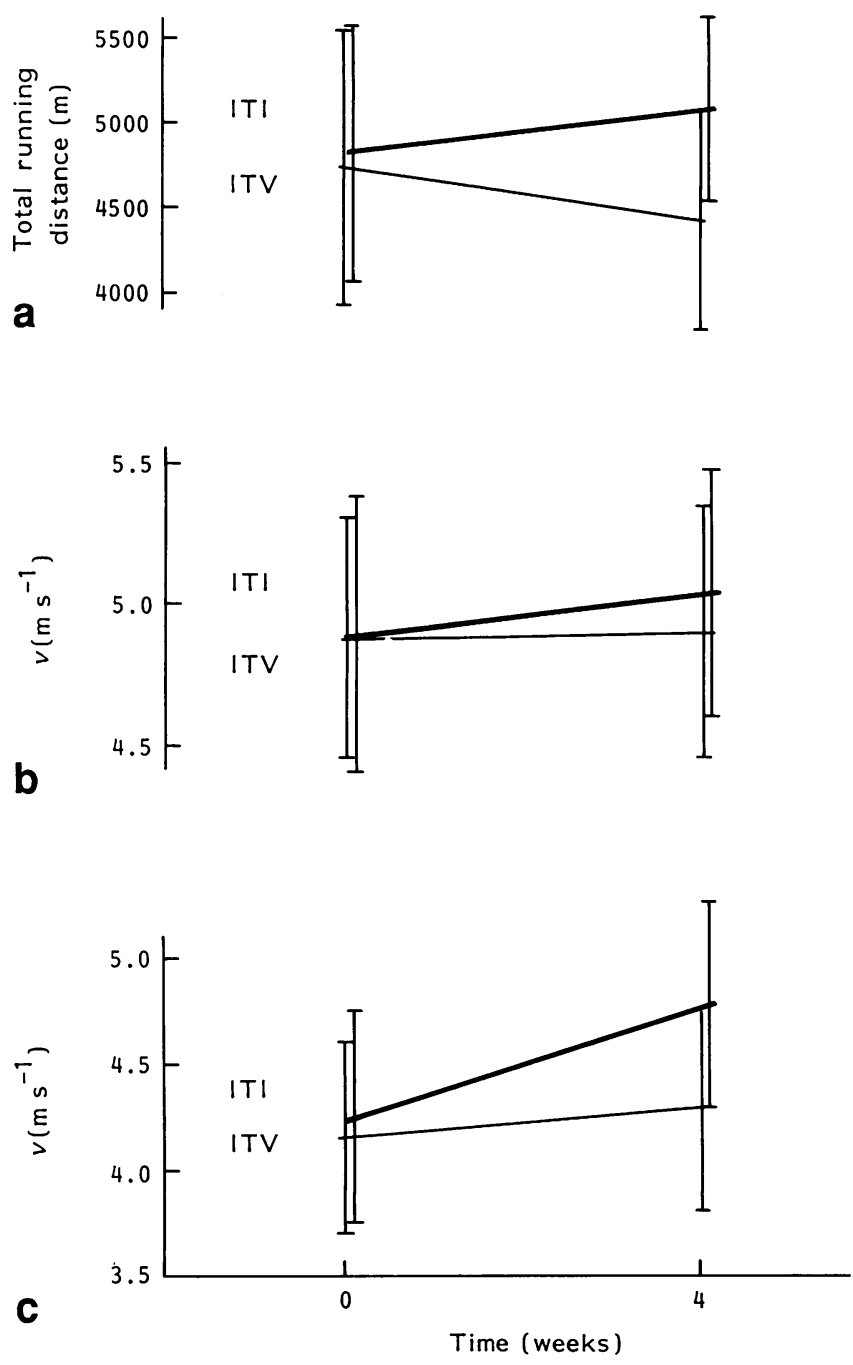

Figure 2. Running speed at b, 2 and c, 4 mmol lactate level increased significantly during the increase in intensity study (ITI) but not during the increase in volume study (ITV). The total running distance decreased in six of eight athletes during ITV and increased in seven of nine athletes during ITI. a ITI, $P<0.10$; ITV,$P<0.10 ;$ b ITI, $P<0.01$; ITV not significant; c ITI, $P<0.01 ;$ ITV,$P<0.05$

sponses, with a decrease in the ITI study. The levels before exercise showed the same trend.

Nocturnal urinary catecholamine elimination is given in Table 5. Catecholamine elimination remained comparatively constant in both studies. Immediately after completion of the ITV study, decreases of $47 \%$ (dopamine), $53 \%$ (noradrenaline) and $48 \%$ (adrenaline) were observed. The decreases following the ITI study were only between 9 and $26 \%$.

Hormonal parameters are displayed in Tables 6 to 8 . The serum levels of cortisol and aldosterone decreased slightly at rest and following maximum exercise in the ITV study, and remained constant following ITI. The exercise-induced prolactin response was also slightly lower in the ITI study. There were no essential differences in dependency on ITV or ITI in the other hormonal parameters (free testosterone, insulin C-peptide, STH, FSH, LH, TSH,

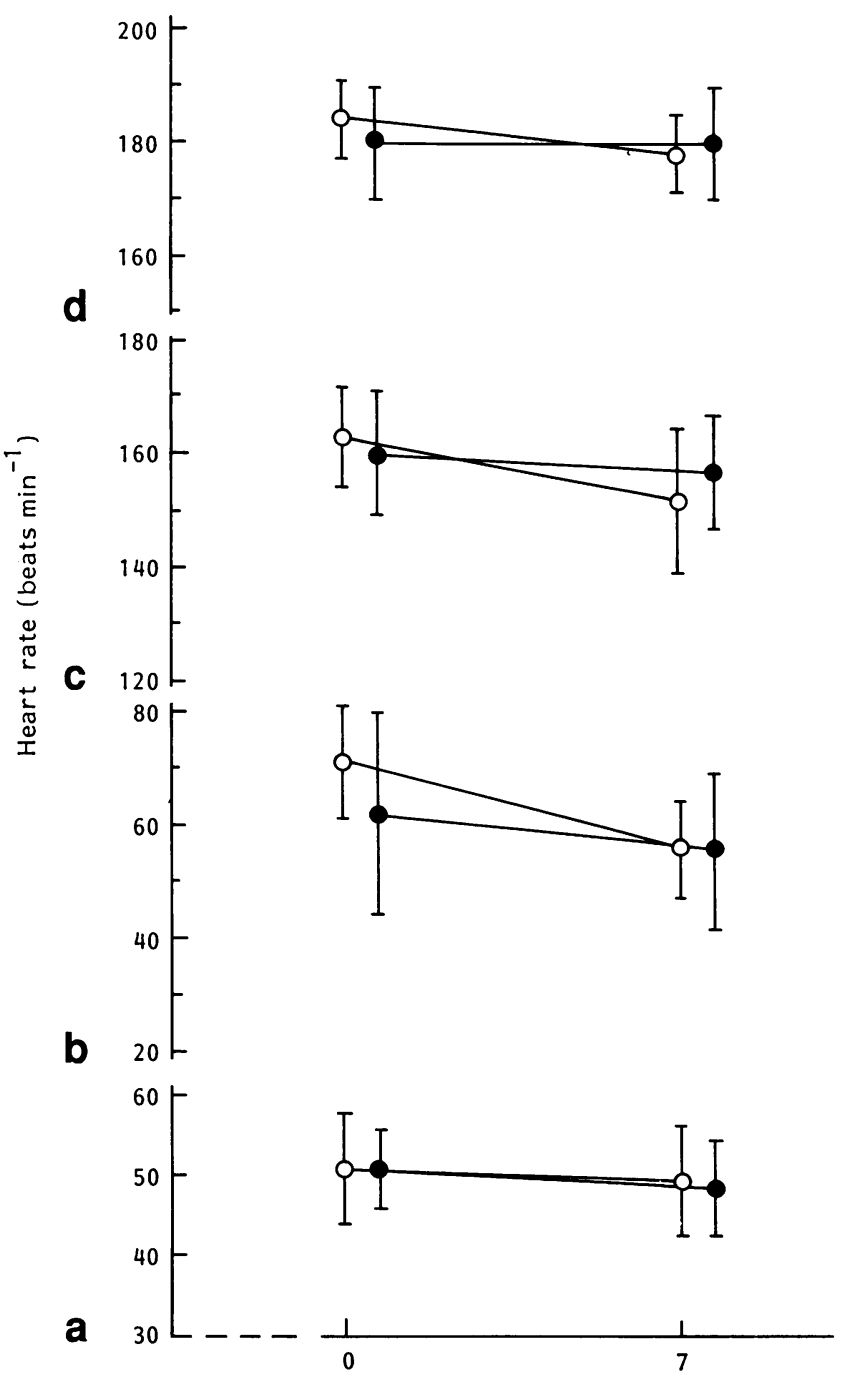

Figure 3. Heart rate a on waking remained constant during the increase in volume $(O)$ and intensity $(O)$ studies. Heart rate $\mathbf{b}$, before ergometric exercise, $\mathbf{c}$ at identical exercise load $\left(v=16 \mathrm{~km} \mathrm{~h}^{-1}\right)$ and $\mathrm{d}$, during maximum treadmill running decreased significantly during the increase in volume study $(P<0.05)$ and remained constant during the increase in intensity study

$\mathrm{T}_{3}$ and $\mathrm{T}_{4}$ ) at the same time of measurement. The resting values of cortisol and aldosterone were already different between the two studies $(P<$ 0.05-0.01), which we consider evidence of the inter-assay variability. The maximum levels also differed between the two studies $(P<0.05)$ for which study-specific effects and the differing baseline values may be responsible. The 24-h cortisol excretion remained constant over 5 weeks in both studies.

\section{Discussion}

The plateau in endurance performance and the decrease in maximum performance (six of eight athletes) with competition incompetence for several months during the ITV study is probably attributable to an exhaustion or overtraining syndrome caused by an imbalance between training and recovery ${ }^{1,3}$. A 
Table 4. Behaviour of free plasma catecholamines

\begin{tabular}{|c|c|c|c|c|c|}
\hline & \multicolumn{2}{|c|}{ Increase in volume study } & \multirow[t]{2}{*}{$P$} & \multicolumn{2}{|c|}{ Increase in intensity study } \\
\hline & 1 & 2 & & 1 & 2 \\
\hline \multicolumn{6}{|l|}{ Dopamine (nmoll-1) } \\
\hline \multicolumn{6}{|l|}{ Before exercise } \\
\hline Median & 2.140 & 1.216 & $t / \neq$ & 0.483 & 0.377 \\
\hline $50 \%$ confidence interval & $0.449-1.898$ & $0.778-1.469$ & & $0.178-0.533$ & $0.241-0.774$ \\
\hline Range & $0.043-3.659$ & $0.702-2.048$ & & $0.045-1.151$ & $0.032-1.606$ \\
\hline \multicolumn{6}{|l|}{ At $v=16 \mathrm{~km} \mathrm{~h}^{-1}$} \\
\hline Median & 1.222 & 1.059 & $\ddagger / \uparrow$ & 0.644 & 0.566 \\
\hline $50 \%$ confidence interval & $1.059-1.632$ & $0.858-1.632$ & & $0.423-0.871$ & $0.416-0.748$ \\
\hline Range & $0.728-4.095$ & $0.215-2.594$ & & $0.299-1.281$ & $0.039-0.806$ \\
\hline \multicolumn{6}{|l|}{ Maximum exercise } \\
\hline Median & 2.691 & 2.594 & $-1+$ & 1.560 & 1.333 \\
\hline $50 \%$ confidence interval & $1.943-2.886$ & $2.275-2.919$ & & $1.203-2.730$ & $0.962-1.892$ \\
\hline Range & $0.143-4.108$ & $0.708-3.367$ & & $0.839-3.062$ & $0.280-2.717$ \\
\hline \multirow{2}{*}{\multicolumn{6}{|c|}{$\begin{array}{l}\text { Noradrenaline }\left(\mathrm{nmol}^{-1}\right) \\
\text { Before exercise }\end{array}$}} \\
\hline & & & & & \\
\hline Median & 3.068 & $3.623^{*}$ & - & 2.950 & 2.301 \\
\hline $50 \%$ confidence interval & $2.714-3.451$ & $3.062-4.189$ & & $2.301-3.481$ & $2.006-2.773$ \\
\hline Range & $2.000-5.800$ & $2.508-8.078$ & & $1.974-3.776$ & $1.770-4.602$ \\
\hline \multicolumn{6}{|l|}{ At $v=16 \mathrm{~km} \mathrm{~h}^{-1}$} \\
\hline Median & 8.779 & $10.284 t$ & - & 8.614 & $7.257 t$ \\
\hline $50 \%$ confidence interval & $6.112-10.555$ & $8.413-13.263$ & & $7.316-11.918$ & $6.077-9.617$ \\
\hline Range & $3.664-12.664$ & $5.994-18.626$ & & $5.251-22.892$ & $4.307-18.526$ \\
\hline \multicolumn{6}{|l|}{ Maximum exercise } \\
\hline Median & 26.816 & 28.267 & $t /-$ & 32.270 & 27.317 \\
\hline $50 \%$ confidence interval & 15.322-37.205 & $26.515-36.899$ & & $27.317-43.542$ & $20.470-39.530$ \\
\hline Range & $11.670-44.693$ & $13.841-52.934$ & & $20.945-56.935$ & $18.762-51.566$ \\
\hline \multicolumn{6}{|l|}{ Adrenaline (nmoll-1) } \\
\hline \multicolumn{6}{|l|}{ Before exercise } \\
\hline Median & 0.977 & 0.813 & - & 0.993 & $0.578+$ \\
\hline $50 \%$ confidence interval & $0.601-1.108$ & $0.650-0.961$ & & $0.633-1.113$ & $0.437-0.841$ \\
\hline Range & $0.235-1.119$ & $0.448-1.327$ & & $0.338-2.020$ & $0.317-1.092$ \\
\hline \multicolumn{6}{|l|}{ At $v=16 \mathrm{~km} \mathrm{~h}^{-1}$} \\
\hline Median & 1.218 & $1.316^{*}$ & - & 1.239 & $0.884 \dagger$ \\
\hline $50 \%$ confidence interval & $0.890-1.322$ & $1.141-1.376$ & & $1.010-1.567$ & $0.688-1.611$ \\
\hline Range & $0.688-2.113$ & $1.016-1.649$ & & $0.497-3.243$ & $0.622-2.490$ \\
\hline \multicolumn{6}{|l|}{ Maximum exercise } \\
\hline Median & 2.413 & 2.588 & $+/-$ & 5.242 & 4.532 \\
\hline $50 \%$ confidence interval & $2.200-3.058$ & $1.867-3.964$ & & $2.730-10.183$ & $1.835-7.043$ \\
\hline Range & $1.370-5.143$ & $1.349-4.646$ & & $1.392-11.062$ & $1.387-10.953$ \\
\hline
\end{tabular}

1 , baseline examination; 2 , final examination; $v$ running velocity (treadmill running)

Statistical examination between both groups $1: 1 / 2: 2$ was conducted using the Wilcoxon Mann-Whitney $U$ test: ${ }^{*} P<0.10 ;+P<0.05$;

$¥ P<0.01$

training cycle of 4 weeks should be long enough to bring improvement in endurance and maximum performance capacity in experienced athletes, since, 1 year later in the same athletes, at the same time of year, ITI resulted in improved performance within a 4-week period (Figure 2) - the examined athletes appeared to demonstrate a 'genetic reserve'. Severe glycogen deficiency is also less likely to cause lack of improvement in performance following ITV because pronounced glycogen deficiency is usually accompanied by lower lactate concentrations ${ }^{8}$, elevated plasma adrenaline levels and tachycardia at the same absolute exercise level ${ }^{9}$. Moreover, a decrease in the insulin level in endurance exercise can be expected in the presence of glycogen deficiency. In the present ITV study, the lactate level remained constant, the adrenaline level showed only a discrete insignificant increase at the same exercise level, the heart rate decreased slightly (Figure 3), and the insulin level showed no significant change (Tables 6 and 7). Assessment of the dietary data also shows no convincing evidence of a severe glycogen deficiency (Table 2).

The significant decrease in the plasma noradrenaline response at the same exercise level in the ITI study is typical of effective endurance training ${ }^{10-12}$, contrary to the ITV study, in which there is an increase in the noradrenaline response (Table 4). Since the plasma half-life of the catecholamines in healthy individuals is not notably dependent on physical training ${ }^{13,14}$, the altered plasma catecholamine levels probably represent a primary expression of altered release. The training status of the skeletal muscle is considered important for the adaptation of sympathetic activity ${ }^{15}$ and afferent conduction pathways have been described ${ }^{16}$. However, it is unclear how their receptors in the musculature are stimulated. There are at least two different mechanisms, since reduction 
Training - overtraining: performance and hormone levels: M. Lehmann et al.

Table 5. Urinary excretion of free catecholamines $\left(\mathrm{pmol} \mathrm{min}^{-1}\right)$ during the $\mathrm{night}^{*}$

\begin{tabular}{|c|c|c|c|c|c|}
\hline & Week 1 & Week 2 & Week 3 & Week 4 & Week 5 \\
\hline \multicolumn{6}{|l|}{$\begin{array}{l}\text { Increase in volume study } \\
\text { Dopamine }\end{array}$} \\
\hline $\begin{array}{l}\text { Median } \\
50 \% \text { confidence interval } \\
\text { Range }\end{array}$ & $\begin{array}{r}1422 \\
1127-2106 \\
857-3519\end{array}$ & $\begin{array}{l}1283 \\
786-1885 \\
552-6025\end{array}$ & $\begin{array}{l}1497 \\
1384-1852 \\
955-2606\end{array}$ & $\begin{array}{l}1475 \\
1046-1963 \\
546-3152\end{array}$ & $\begin{array}{l}764 \ddagger \\
513-1003 \\
273-2800\end{array}$ \\
\hline $\begin{array}{l}\text { Noradrenaline } \\
\text { Median } \\
50 \% \text { confidence interval } \\
\text { Range }\end{array}$ & $\begin{array}{l}178 \\
125-348 \\
98-551\end{array}$ & $\begin{array}{l}164 t \\
97-182 \\
91-483\end{array}$ & $\begin{array}{l}166 \\
108-237 \\
94-626\end{array}$ & $\begin{array}{l}160 \\
150-187 \\
80-327\end{array}$ & $\begin{array}{l}85 \S \\
78-96 \\
64-126\end{array}$ \\
\hline $\begin{array}{l}\text { Adrenaline } \\
\text { Median } \\
50 \% \text { confidence interval } \\
\text { Range }\end{array}$ & $\begin{array}{l}50 \\
37-86 \\
23-213\end{array}$ & $\begin{array}{l}47 \\
24-62 \\
16-218\end{array}$ & $\begin{array}{l}47 \\
25-75 \\
17-149\end{array}$ & $\begin{array}{l}50 \\
43-65 \\
9-142\end{array}$ & $\begin{array}{l}26 \S \\
24-27 \\
13-42\end{array}$ \\
\hline \multicolumn{6}{|l|}{$\begin{array}{l}\text { Increase in intensity study } \\
\text { Dopamine }\end{array}$} \\
\hline $\begin{array}{l}\text { Median } \\
50 \% \text { confidence interval } \\
\text { Range } \\
\text { Noradrenaline }\end{array}$ & $\begin{array}{l}1296 \\
1191-1487 \\
533-1946\end{array}$ & $\begin{array}{l}1205 \\
945-1268 \\
515-1949\end{array}$ & $\begin{array}{l}1176 \\
1106-1249 \\
604-1553\end{array}$ & $\begin{array}{l}884 \\
765-953 \\
571-1378\end{array}$ & $\begin{array}{l}968+ \\
663-1044 \\
449-2320\end{array}$ \\
\hline $\begin{array}{l}\text { Median } \\
50 \% \text { confidence interval } \\
\text { Range }\end{array}$ & $\begin{array}{l}126 \\
98-137 \\
70-180\end{array}$ & $\begin{array}{l}146+ \\
139-157 \\
67-187\end{array}$ & $\begin{array}{l}126 \\
102-137 \\
60-150\end{array}$ & $\begin{array}{l}117 \\
90-129 \\
79-138\end{array}$ & $\begin{array}{l}103 \ddagger \\
93-118 \\
48-151\end{array}$ \\
\hline $\begin{array}{l}\text { Adrenaline } \\
\text { Median } \\
50 \% \text { confidence interval } \\
\text { Range }\end{array}$ & $\begin{array}{l}33 \\
27-41 \\
20-50\end{array}$ & $\begin{array}{l}35 \\
31-50 \\
19-59\end{array}$ & $\begin{array}{l}38 \\
32-44 \\
20-58\end{array}$ & $\begin{array}{l}24 t \\
23-28 \\
22-57\end{array}$ & $\begin{array}{l}30 \\
26-36 \\
14-64\end{array}$ \\
\hline
\end{tabular}

* There are no significant differences in urinary catecholamine excretion between both examinations, except for noradrenaline excretion in week 1 (Wilcoxon Mann-Whitney $U$ test, $P<0.05$ ); noradrenaline, adrenaline and dopamine excretions decreased significantly during ITV, dopamine and noradrenaline during ITI (Dixon and Mood sign test: $+P<0.10 ; \neq P<0.05 ; \S P<0.01$ )
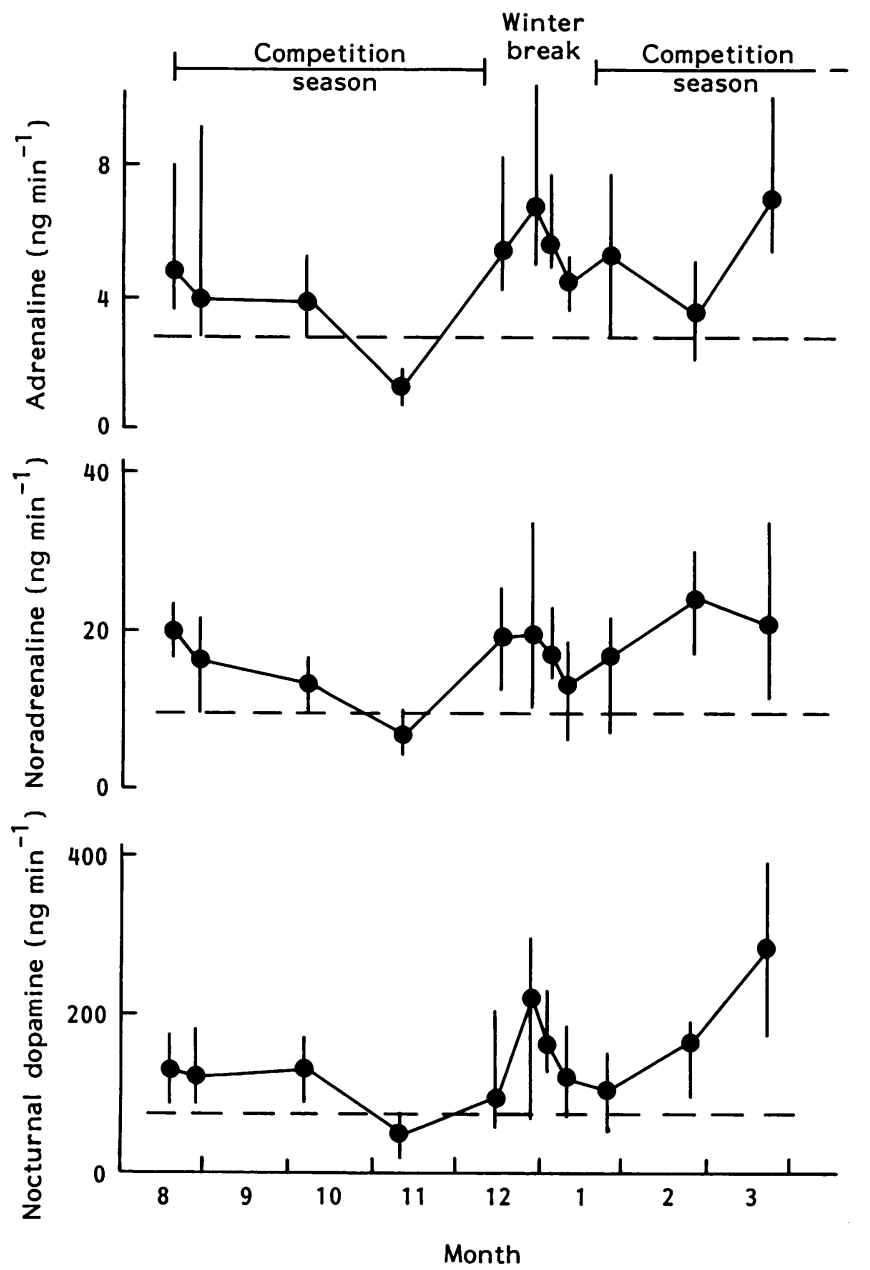

Figure 4. A significant decrease in excretion of nocturnal dopamine, noradrenaline and adrenaline was observed in 16 soccer players from August to November $1990(P<$ 0.001 ). The running speed at $4 \mathrm{mmol}$ lactate level was simultaneously decreased in November compared with August $(P<0.05)$ - the team was in places two and three in August-September and in places six and seven in November-December. Decrease in nocturnal catecholamine excretion (more than $50 \%$ for noradrenaline and adrenaline), in running speed at $4 \mathrm{mmol}$ lactate level, and in the league rank may point to an exhaustion syndrome. During the recovery period (winter break) a reincrease in nocturnal catecholamine excretion was observed, running speed at $4 \mathrm{mmol}$ lactate level remained constant and the team was in the second league rank after February $1991^{28}$ 
in catecholamine levels is not only observed when the aerobic work capacity of the muscles is improved $^{10-12}$, but also when muscular strength is increased $^{17,18}$.

The higher catecholamine level at the identical exercise rates, coupled with a lower heart rate on day 28 of the ITV study may indicate a reduced sensitivity to catecholamines in exhaustion, since the constancy of heart rate in the morning on waking contradicts a decisive increase in vagotonia. A marked decrease in sensitivity to catecholamines is thus found in experiments with long-term stimulation for hours with isoproterenol ${ }^{19}$. We therefore hypothesize that excessive training volume coupled with a neglect of rest and relaxation leads to a loss of sensitivity to catecholamines as an expression of 'peripheral exhaustion'. This hypothesis is still to be confirmed.

We view the more marked decrease in basal catecholamine elimination in the ITV study as an indicator of a decrease in intrinsic sympathetic activity, caused by hypothalamic dysfunction ${ }^{20}$ as an equivalent of 'central fatigue' in exhausted athletes.

Table 6. Behaviour of hormones at baseline, interim and final examination (a) before ergometry and (b) after maximum ergometric exercise during the increase in volume study

\begin{tabular}{|c|c|c|c|c|c|c|}
\hline & \multicolumn{2}{|c|}{ Baseline } & \multicolumn{2}{|c|}{ Interim } & \multicolumn{2}{|c|}{ Final } \\
\hline & $a$ & $b$ & a & $b$ & a & $b$ \\
\hline \multicolumn{7}{|l|}{ Cortisol $\left(\mathrm{nmol} \mathrm{I}^{-1}\right)$} \\
\hline Median & 425 & 425 & 391 & 438 & $336^{*}$ & $378+$ \\
\hline $50 \%$ confidence interval & 314-485 & $408-499$ & $369-452$ & $400-579$ & $267-372$ & $317-430$ \\
\hline Range & $201-701$ & $284-814$ & $322-452$ & $257-742$ & $168-444$ & $267-574$ \\
\hline \multicolumn{7}{|l|}{ Aldosterone $\left(\mathrm{nmoll}^{-1}\right)$} \\
\hline Median & 207 & 1559 & 238 & 1473 & $160^{*}$ & $1052^{*}$ \\
\hline $50 \%$ confidence interval & 144-407 & $1102-1758$ & $182-326$ & $1121-1941$ & $113-263$ & $936-1163$ \\
\hline Range & $63-581$ & $509-2808$ & $127-526$ & $642-2792$ & $36-354$ & $517-2265$ \\
\hline \multicolumn{7}{|l|}{ Testosterone (pmoll $\mathrm{I}^{-1}$ ) } \\
\hline Median & 69 & 83 & 65 & 76 & 62 & 83 \\
\hline $50 \%$ confidence interval & $44-72$ & $62-96$ & $62-69$ & $62-86$ & $58-69$ & 79-89 \\
\hline Range & $41-96$ & $51-131$ & $44-76$ & $44-100$ & 44-93 & $55-124$ \\
\hline \multicolumn{7}{|l|}{ Insulin $\left(\mu \cup \mathrm{ml}^{-1}\right)$} \\
\hline Median & 7 & 14 & 6 & 10 & 8 & 8 \\
\hline $50 \%$ confidence interval & $5-9$ & $7-21$ & $5-8$ & $5-12$ & $5-9$ & 8-10 \\
\hline Range & $2-13$ & $5-40$ & $2-17$ & $4-36$ & $2-14$ & $5-18$ \\
\hline \multicolumn{7}{|l|}{ C-Peptide (ng m/ $\left.I^{-1}\right)$} \\
\hline Median & 1.9 & 2.3 & 1.9 & 1.8 & 2.3 & 2.0 \\
\hline $50 \%$ confidence interval & $1.7-2.2$ & $1.8-2.8$ & $1.5-2.2$ & $1.6-2.4$ & $2.0-2.4$ & $1.6-2.3$ \\
\hline Range & $1.4-2.4$ & $1.4-3.6$ & $1.0-3.0$ & $1.4-3.4$ & $1.5-3.2$ & $1.4-2.4$ \\
\hline \multicolumn{7}{|l|}{$G H\left(n g m l^{-1}\right)$} \\
\hline Median & 2.6 & 5.0 & 1.6 & 3.6 & 2.3 & 7.1 \\
\hline $50 \%$ confidence interval & $0.6-3.0$ & $2.9-5.1$ & $0.5-2.3$ & $3.3-10.0$ & $0.2-2.5$ & $3.2-13.2$ \\
\hline Range & $0.1-4.0$ & $1.8-32$ & $0.1-9.5$ & $2.8-19$ & $0.1-5.1$ & $0.2-22$ \\
\hline \multicolumn{7}{|l|}{ Prolactin $\left(\mu \cup m l^{-1}\right)$} \\
\hline Median & 117 & 414 & 119 & 350 & 115 & 384 \\
\hline $50 \%$ confidence interval & $92-141$ & $344-610$ & $89-126$ & $309-405$ & $97-131$ & $262-340$ \\
\hline Range & $67-182$ & $166-666$ & $52-142$ & $87-560$ & $64-174$ & $138-661$ \\
\hline \multicolumn{7}{|l|}{$F S H\left(\mu \cup m l^{-1}\right)$} \\
\hline Median & 3.7 & 4.4 & 3.3 & 3.9 & 3.5 & 4.0 \\
\hline $50 \%$ confidence interval & $3.2-4.8$ & $3.8-5.4$ & $3.1-4.8$ & $3.4-5.4$ & $3.0-5.2$ & $3.3-5.8$ \\
\hline Range & $1.8-6.9$ & $2.1-8.1$ & $2.2-7.5$ & $2.4-7.9$ & $1.8-6.5$ & $2.2-6.9$ \\
\hline \multicolumn{7}{|l|}{$L H\left(\mu \cup m l^{-1}\right)$} \\
\hline Median & 2.7 & 3.1 & 2.2 & 2.8 & 3.1 & 2.8 \\
\hline $50 \%$ confidence interval & $2.5-2.8$ & $2.5-4.5$ & $1.5-2.9$ & $2.2-3.6$ & $1.7-4.1$ & $1.9-4.0$ \\
\hline Range & $1.6-4.2$ & $1.6-5.7$ & $1.4-5.6$ & $1.1-4.8$ & $1.4-4.6$ & $1.4-5.9$ \\
\hline \multicolumn{7}{|l|}{$T S H\left(\mu \cup m l^{-1}\right)$} \\
\hline Median & 0.97 & 1.3 & 0.87 & 1.02 & 0.87 & 1.25 \\
\hline $50 \%$ confidence interval & $0.9-1.1$ & $1.0-1.9$ & $0.7-0.9$ & $0.9-1.3$ & $0.7-1.1$ & $1.0-1.5$ \\
\hline Range & $0.1-2.0$ & $0.8-2.8$ & $0.5-1.9$ & $0.7-2.2$ & $0.6-1.8$ & $0.9-2.6$ \\
\hline \multicolumn{7}{|l|}{ Triiodothyronine (nmoll-1) } \\
\hline Median & 1.68 & - & 1.68 & - & 1.59 & - \\
\hline $50 \%$ confidence interval & $1.53-1.83$ & - & $1.53-1.82$ & - & $1.37-1.68$ & - \\
\hline Range & $1.37-1.85$ & - & $1.22-3.14$ & - & $1.20-1.69$ & - \\
\hline \multicolumn{7}{|l|}{ Thyroxine $\left(\mathrm{nmol}^{-1}\right)$} \\
\hline Median & 94 & - & 100 & - & 96 & - \\
\hline $50 \%$ confidence interval & 90-105 & - & 97-101 & - & 83-100 & - \\
\hline Range & $75-142$ & - & $68-129$ & - & 69-106 & - \\
\hline
\end{tabular}

${ }^{*} P<0.10 ;+P<0.05 ;$ Dixon and Mood sign test 
Training - overtraining: performance and hormone levels: M. Lehmann et al.

Table 7. Behaviour of hormones at baseline, interim and final examination (a) before ergometry and (b) after maximum ergometric exercise during the increase in intensity study

\begin{tabular}{|c|c|c|c|c|c|c|}
\hline & \multicolumn{2}{|c|}{ Baseline } & \multicolumn{2}{|c|}{ Interim } & \multicolumn{2}{|c|}{ Final } \\
\hline & $a$ & $b$ & $a$ & $b$ & $a$ & $b$ \\
\hline \multicolumn{7}{|l|}{ Cortisol $\left(\mathrm{nmoll}^{-1}\right)$} \\
\hline Median & 262 & 364 & 215 & 295 & 320 & 331 \\
\hline $50 \%$ confidence interval & $237-300$ & $292-419$ & $168-270$ & $218-320$ & $259-361$ & $300-389$ \\
\hline Range & $182-358$ & $212-513$ & $93-413$ & $146-339$ & $176-554$ & $190-538$ \\
\hline \multicolumn{7}{|l|}{ Aldosterone $\left(\mathrm{nmol} \mathrm{I}^{-1}\right)$} \\
\hline Median & 113 & 711 & 191 & 972 & $240^{*}$ & 731 \\
\hline $50 \%$ confidence interval & $102-229$ & $554-1094$ & $181-282$ & 578-933 & 188-301 & 722-908 \\
\hline Range & $58-379$ & $487-1811$ & $88-725$ & 493-2606 & $66-598$ & 529-1102 \\
\hline \multicolumn{7}{|l|}{ Testosterone (pmoll-1) } \\
\hline Median & 69 & 89 & 69 & 89 & 65 & 93 \\
\hline $50 \%$ confidence interval & $55-72$ & $83-103$ & $62-79$ & $83-100$ & $62-83$ & $86-103$ \\
\hline Range & $41-110$ & $41-93$ & $44-100$ & $51-141$ & $44-121$ & $83-159$ \\
\hline \multicolumn{7}{|l|}{ Insulin $\left(\mu \cup \mathrm{ml}^{-1}\right)$} \\
\hline Median & 9 & 13 & 7 & 12 & 10 & 11 \\
\hline $50 \%$ confidence interval & $6-12$ & $9-19$ & $5-10$ & $9-17$ & $8-18$ & $9-18$ \\
\hline Range & $4-24$ & $7-26$ & $4-26$ & $8-28$ & $5-22$ & $5-21$ \\
\hline \multicolumn{7}{|l|}{ C-Peptide (ng m/-1) } \\
\hline Median & 2.2 & 2.8 & 2.2 & 1.7 & 2.2 & 2.1 \\
\hline $50 \%$ confidence interval & $1.3-2.6$ & $1.7-2.6$ & $1.1-2.4$ & $1.6-2.4$ & $1.8-2.8$ & $1.9-2.2$ \\
\hline Range & $1.0-3.1$ & $1.3-2.9$ & $0.9-2.9$ & $1.3-2.9$ & $1.4-3.8$ & $1.7-4.1$ \\
\hline \multicolumn{7}{|l|}{$G H\left(n g m l^{-1}\right)$} \\
\hline Median & 1.9 & 9.0 & 1.0 & 3.3 & 1.3 & 11.5 \\
\hline $50 \%$ confidence interval & $0.4-3.5$ & $2.0-12.0$ & $0.3-2.0$ & $2.8-7.4$ & $0.6-3.8$ & 2.9-18.1 \\
\hline Range & $0.2-4.8$ & $1.3-29.1$ & $0.2-32.0$ & $1.0-27.3$ & $0.1-13$ & $1.0-25$ \\
\hline \multicolumn{7}{|l|}{ Prolactin $\left(\mu \cup \mathrm{ml}^{-1}\right)$} \\
\hline Median & 93 & 353 & 81 & 289 & 113 & $204^{*}$ \\
\hline $50 \%$ confidence interval & 78-135 & $243-423$ & $68-100$ & $149-338$ & $109-116$ & $171-368$ \\
\hline Range & $40-150$ & $72-579$ & $35-114$ & $82-489$ & $37-188$ & $46-421$ \\
\hline \multicolumn{7}{|l|}{$F S H\left(\mu \cup m l^{-1}\right)$} \\
\hline Median & 5.5 & 6.2 & 5.9 & 6.2 & 6.6 & 6.7 \\
\hline $50 \%$ confidence interval & $4.8-6.3$ & $5.6-6.6$ & $4.0-6.2$ & $3.9-6.8$ & $3.9-6.8$ & $5.2-7.2$ \\
\hline Range & $2.0-7.5$ & $2.2-8.0$ & $1.9-6.7$ & $2.1-7.2$ & $1.5-7.2$ & $2.0-7.9$ \\
\hline \multicolumn{7}{|l|}{$L H\left(\mu \cup m l^{-1}\right)$} \\
\hline Median & 2.5 & 2.6 & 3.1 & 2.9 & 3.4 & 3.2 \\
\hline $50 \%$ confidence interval & 2.4-3.7 & $2.3-3.1$ & $2.8-3.3$ & $2.0-3.0$ & $1.8-3.7$ & $2.9-3.8$ \\
\hline Range & $2.0-4.0$ & $2.1-4.8$ & $2.1-5.3$ & $2.0-3.8$ & $1.5-4.9$ & $1.8-4.0$ \\
\hline \multicolumn{7}{|l|}{$T S H\left(\mu \cup m l^{-1}\right)$} \\
\hline Median & 0.74 & 1.06 & 0.80 & 1.17 & 0.80 & $0.92^{*}$ \\
\hline $50 \%$ confidence interval & $0.7-0.9$ & $0.9-1.2$ & $0.7-1.0$ & $0.8-1.3$ & $0.5-1.0$ & $0.7-1.2$ \\
\hline Range & $0.6-1.0$ & $0.7-1.8$ & $0.5-1.4$ & $0.7-1.6$ & $0.3-1.4$ & $0.8-1.8$ \\
\hline \multicolumn{7}{|l|}{ Triiodothyronine (nmoll-1) } \\
\hline Median & 1.53 & & 1.53 & & 1.37 & \\
\hline $50 \%$ confidence interval & $1.37-1.68$ & & $1.36-1.68$ & & $1.22-1.52$ & \\
\hline Range & $1.22-1.69$ & & $1.22-1.69$ & & $1.07-1.53$ & \\
\hline \multicolumn{7}{|l|}{ Thyroxine (nmoll-1) } \\
\hline Median & 100 & & 96 & & 105 & \\
\hline $50 \%$ confidence interval & 86-109 & & $92-109$ & & $88-117$ & \\
\hline Range & 79-114 & & $88-120$ & & $84-129$ & \\
\hline
\end{tabular}

$P<0.10 ;$ Dixon and Mood sign test

Table 8. 24-h urinary cortisol excretion ( $\left.\mathrm{nmol} 24 \mathrm{~h}^{-1}\right)$

\begin{tabular}{llllll}
\hline & Week 1 & Week 2 & Week 3 & Week 4 & Week 5 \\
\hline $\begin{array}{l}\text { Increase in volume study } \\
\text { Median }\end{array}$ & 289 & & & 289 & 278 \\
$\quad 50 \%$ confidence interval & $245-344$ & $206^{*}$ & $264-314$ & $184-352$ & $267-314$ \\
$\begin{array}{l}\text { Increase in intensity study } \\
\text { Median }\end{array}$ & 265 & $184-267$ & 247 & 278 & 291 \\
$50 \%$ confidence interval & $231-339$ & $271-292$ & $199-289$ & $186-347$ & $257-331$ \\
\hline
\end{tabular}

${ }^{*} P<0.05$; Wilcoxon Mann-Whitney $U$ test 
The maximum plasma catecholamine response is, however, still unchanged or even elevated (Table 4). A reduction in the maximum catecholamine response is assumed if overexertion continues for more than 4 weeks. In a further prospective study we recently confirmed our hypothesis, that exhaustion is accompanied by a profound decrease and recovery by an increase in the decreased basal catecholamine excretion (Figure 4). The clear decrease in basal catecholamine excretion and the behaviour of cortisol and testosterone in the present study do not confirm specifically the hypothesis of increased catabolism in overtrained athletes such as is assumed on the basis of the cortisol-testosterone ratio ${ }^{2,21}$.

The different behaviour of cortisol and aldosterone levels between the two studies is probably not important in diagnosing performance since these changes are too small to be reliably differentiated from inter-assay variance in cross-sectional studies. Also to be considered are the different baseline values of the two studies, which are also most likely due to inter-assay variability. The decrease in resting and exercise cortisol concentration following ITV (Table 6) does not indicate decreased cortisol metabolism, since the 24-h excretion of cortisol remains constant (Table 8). The observed decrease in basal cortisol level (ITV) contradicts the findings of Barron et al. ${ }^{20}$ and Adlerkreuz et $a .^{21}$. These authors described increased 'catabolic' cortisol levels in 'overtrained athletes'. Their studies were, however, performed only on four athletes ${ }^{20}$ or for 1 week only ${ }^{21}$. Additional prospective experimental data were therefore necessary.

With the exception of the slight exercise-induced decrease in prolactin during the ITI study, no performance-differential diagnostic statements could be made for the other hormonal parameters examined. This is especially true for free testosterone. In intensive training phases, a decrease in basal free testosterone of about $10 \%$ can be expected ${ }^{2}$. This, however, is within the range of variation of the assay method. In the present study, the median value decreased by $10 \%$ following ITV but this change was not significant. A decrease of up to $40 \%$ of the total testosterone level following exhaustive endurance exercise has been described by various authors ${ }^{22-27}$, but not as yet for free testosterone. On the morning after $15-\mathrm{km}$ and $25-\mathrm{km}$ runs, the basal levels of total testosterone were nearly back to baseline values ${ }^{25}$ but after a marathon race, the level remained reduced for 2-3 days ${ }^{25}$. However, it is unclear whether these results can be transferred to high-performance athletes.

Overall, it must be stated that only a possible and marginal differential diagnostic relevance was found in the parameters measured in these studies for plasma catecholamines, cortisol and aldosterone. In practice, these are probably only useful in longitudinal studies. However, the differences in basal catecholamine excretion appear somewhat clearer. Nevertheless even these results strictly apply only to the current study. To generalize further would require additional experimental studies and confirmation by other workers.

\section{Acknowledgements}

These studies were supported by grants from Deutsche Forschungsgemeinschaft Le 687/1-1) and Bundesinstitut für Sportwissenschaften, Köln-Lövenich. Many thanks to Ms J. Eysell for translation of our manuscript and to Ms U. Spöri for technical assistance.

\section{References}

1 Israel S. Zur Problematik des Übertrainings aus internistischer und leistungsphysiologischer Sicht. Medizin und Sport 1976; 16: $1-12$.

2 Kindermann M, Urhausen A. Möglichkeiten einer hormonellen Trainingssteuerung. In: Böning D, Braumann KM, Busse MW, Maassen N, Schmidt W, eds. Sport, Rettung oder Risiko für die Gesundheit. Köln: Deutscher Ärzte-Verlag, 1989; 297-304.

3 Kuipers H, Keizer HA. Overtraining in elite athletes. Sports Med 1988; 6: 79-92.

4 Hohorst HJ. L-(+)-Laktat. Bestimmung mit Laktatdehydrogenase und DPN. In: Bergmeyer $\mathrm{HU}$, ed. Methoden der enzymatischen Analyse. Weinheim: Verlag Chemie, 1962; 266-77.

5 Da Prada $M$, Zürcher G. Simultaneous radioenzymatic determination of plasma and tissue adrenaline, noradrenaline and dopamine within the fentomole range. Life Sci 1976; 19: 1161-74.

6 Lehmann M, Keul J. Capillary-venous differences of free plasma catecholamines at rest and during graded exercise. Eur J Appl Physiol 1985; 54: 502-5.

7 Sachs L. Angewandte Statistik. Berlin: Springer, 1978; 230-5, 247-50.

8 Braumann KM, Maassen N, Busse M. Die Problematik der Interpretation trainings-begleitender Laktatmessungen. Dtsch Z Sportmed 1988; 39: 365-8.

9 Galbo H, Christensen NJ, Nikines KJ et al. The effect of fasting on the hormonal response to graded exercise. J Clin Endocrinol Metab 1981; 52: 1106-12.

10 Harley LH, Mason JW, Hogan RP et al. Multiple hormonal responses to graded exercise in relation to physical training. J Appl Physiol 1972; 33: 602-6.

11 Péronnet F, Cléroux J, Perrault H, Cousineau D, Champlain J, Nadeau R. Plasma norepinephrine response to exercise before and after training in humans. J Appl Physiol 1981; 51: 812-15.

12 Winder WW, Hickson RC, Hagberg JM, Ehsani AA, McLane JA. Training induced changes in hormonal and metabolic responses to submaximal exercise. J Appl Physiol 1979; 46: 766-71.

13 Hagberg JM, Hickson RC, McLane JA, Ehsani AA, Winder WW. Disappearance of norepinephrine from the circulation following strenuous exercise. I Appl Physiol 1979; 47: 131-14

14 Lehmann M, Jalob E, Dickhuth HH, Korsten-Reck U, Keul J. Sympathische Aktivität in Beziehung zu Leistungsdiagnostik, Training und Übertraining. In: Böning D, Braumann KM, Busse MW, Maassen N, Schmidt W, eds. Sport, Rettung oder Risiko für die Gesundheit. Köln: Deutscher Ärzte-Verlag, 1989; 127-35.

15 Trap-Jensen J, Christensen NJ, Clausen JP, Rasmussen B, Klausen $\mathrm{K}$. Arterial noradrenaline and circulatory adjustment to strenuous exercise with trained and non-trained muscle groups. In: Selinger V, ed. Physical Fitness. Prague CSSR: University Karlova Press, 1973: 414-18.

16 Kniffki KD, Mense S, Schmidt RF. Muscle receptors with fine afferent fibers which may evoke circulatory reflexes. Circ Res 1981; 48 (Suppl 1): 25-31.

17 Guezennec Y, Leger L, Lhoste F, Aymond M, Pesquies PC Hormone and metabolic response to weight lifting training sessions. Int J Sports Med 1986; 7: 100-105.

18 Lehmann M, Berg A, Dickhuth $\mathrm{HH}$ et al. Zur Bedeutung von Katecholamin- und Adrenorezeptorverhalten für Leistungsdiagnostik und Trainingsbegleitung. Leistungssport 1989; 19: 14-21. 
19 Tohmeh JF, Cryer PE. Biphasic adrenergic modulation of $\beta$-adrenergic receptors in man. J Clin Invest 1980; 65: 836-40.

20 Barron GL, Noakes TD, Levy W, Smith C, Millar EP. Hypothalamic dysfunction in overtrained athletes. J Clin Endocrinol Metab 1985; 60: 803-6.

21 Adlerkreuz $\mathrm{H}$, Harkonen $M$, Kuopasalmi $\mathrm{K}$ et al. Effect of training on plasma anabolic and catabolic steroid hormones and their response during physical exercise. Int J Sports Med 1986; 7 (Suppl): 27-8.

22 Dufaux B, Hoederath A, Heck $H$, Hollmann W. Serum testosterone levels during the first hours and days after a prolonged physical exercise and the influence of physical training. Fourth Int Symf Biochem Exer. Abstract 47, Brüssel, 1979.

23 Dufaux B, Assmann G, Order U, Hoederath A, Hollmann W. Plasma lipoproteins, hormones and energy substrates during the first days after prolonged exercise. Int J Sports Med 1981; 2: 256-60.

24 Keizer HA, Kuipers H, Haan de J, Beckers E, Habets L.
Multiple hormonal responses to exercise in trained and untrained women. Int J Sports Med 1987; 8 (Suppl 3): 139-50.

25 Keizer H, Janssen GME, Menheere P, Kranenburg G. Changes in basal plasma testosterone, cortisol and dehydroepiandrosterone sulfate in previously untrained males and females preparing for a marathon. Int J Sports Med 1989; 10: $139-45$.

26 Kuoppasalmi K, Naneri $H$, Harkonen $M$, Adlerkreuz $H$. Plasma cortisol, androstenedione, testosterone and luteinizing hormone in running exercise of different intensities. J Clin Lab Invest 1980; 40: 403-9.

27 Kuoppasalmi K, Adlerkreuz H. Interaction between catabolic and anabolic steroid hormones in muscular exercise. In Fotherby K, Pal SB, eds. Exercise Endocrinology. Berlin: W de Gruyter, 1985: 65-156.

28 Lehmann M, Schnee W, Scheu R, Stockhausen W, Bachl N. Decreased nocturnal catecholamine excretion: parameter for an overtraining syndrome in athletes? Int J Sports Med 1992; 13: 236-72.

\section{Courses in Sports Medicine}

We apologise for the misleading title to Courses in Sports Medicine in the September issue which gave the impression that the courses were run by BASM which is not the case.

\section{British Association of Sport and Medicine}

One week/weekend introductory and advanced courses in sports medicine for medical practitioners and physiotherapists.

Contact: Ms Nancy Laurenson, BASM Education Officer, London Sports Medicine Institute, c/o Medical College of St. Bartholomew's Hospital, Charterhouse Square, London EC1M 6BQ UK. Tel: 071-253 3244 and 071-251 0583; Fax: 071-251 0774

\section{London Sports Medicine Institute}

Three-year part-time course in sports medicine for general practitioners. Contact: Academic Secretary, London Sports Medicine Institute, c/o Medical College of St. Bartholomew's Hospital, Charterhouse Square, London EC1M 6BQ UK. Tel: 071-251 0583; Fax: 071-251 0774

\section{The London Hospital Medical College}

One-year full-time diploma course in sports medicine for medical practitioners. Contact: Mrs Dot Blake, The Diploma Course in Sports Medicine, Department of Sports Medicine, London Hospital Medical College, 1st Floor Fielden House, Stepney Way, London E1 1BB, UK

Tel: 071-377 7389
4. University of Nottingham Medical School

Two-year part-time MSc in sports medicine for medical practitioners and chartered physiotherapists with a first degree or equivalent.

Contact: Professor E. Idris Williams, Department of General Practice, The Medical School, Queens Medical Centre, Nottingham NG7 2UH, UK. Tel: (0602) 709396; Fax: (0602) 709389

\section{The University of Bath}

A modular course in sports medicine by distance learning for medical practitioners Contact: Mrs Sally Jeffries, Distance Learning Unit, Centre for Continuing Education, University of Bath, Claverton Down, Bath BA2 7AY, UK. Tel: (0225) 826342; Fax: (0225) 826849

\section{Association of Chartered} Physiotherapists in Sports Medicine Six-month practical course leading to certificate in sports physiotherapy and a two-year part-time academic course leading to a diploma in sports physiotherapy.

Contact: Dr Ian Roberts, Assistant Director, Crewe and Alsager College of Higher Education, Hassall Road, Alsager, Cheshire ST7 2HL, UK. Tel (0270) 882500
7. Diploma in Academic and Practical Physiotherapy for Sports

One-year part-time course in sports medicine/physiotherapy for chartered physiotherapists.

Contact: Joanne Marshall, Department of Sports Medicine, London Hospital Medical College, 1st Floor Fielden House, Stepney Way, London E1 1BB, UK. Tel: 071-247 7636

\section{Edinburgh Post-Graduate Board for} Medicine

One-week introductory course in sports medicine for doctors and physiotherapists. Contact: Dr Elizabeth McSwan, Moray House College of Education Cramond Campus, Cramond Road North, Edinburgh EH4 6JD, UK. Tel: 0313126001

9. Diploma in Podiatric Sports Medicine Two-year part-time course in sports podiatry.

Contact: Dr Ian Roberts, Assistant Director, Crewe and Alsager College of Higher Education, Hassall Road, Alsager,

Cheshire ST7 2HL, UK.

Tel: (0270) 882500 